\title{
Social inequities in health - an overview with five perspectives
}

\author{
Peter F. Hjort \\ Bjerkåsen 32, 1365 Blommenholm \\ Telefon og telefax: 67542836
}

\begin{abstract}
SUMMARY
Health is the wish of everybody, but the responsibility of nobody. This is particularly obvious for the social inequities in health. I discuss five perspectives:

Research - has documented social inequities in health in most countries, but we need more knowledge about the mechanisms and, especially, about effective interventions.

Health services - should give higher priorities to areas of special importance to the underprivileged ("macro"), e.g. to children from families in difficulties, and should be especially careful with underprivileged patients ("micro").

Schools and kindergartens - have an important role and should give high priority to children from families in difficulties.

Working life - is geared for economic growth and competition and favours the winners. As a society we need a working life which is responsible for people, not only for profit.

Politics - is ultimately responsible for social inequities. Two generations ago, the majority was poor, and politics was aimed for economic growth and welfare for all. Today, the poor are a minority and therefore carry less political weight.

My conclusion is that social inequities in health should be the responsibility of all of us, and the masterword is Dostojevskij's: "We are all responsible to all and for all."
\end{abstract}

\section{NORSK SAMMENDRAG}

Alle drømmer om at helsen, og folkehelsen, skal bli bedre. Levealderen øker, og gamle er friskere enn før. Men ett problem er like uløst, og det er de sosiale ulikhetene i helse. De forsvinner ikke, for ingen vil ha ansvar for dem. I denne artikkelen drøfter jeg fem perspektiver.

Forskningen - har dokumentert sosiale helseforskjeller i alle land, men vi mangler kunnskaper om mekanismene og om det vi trenger mest: effektiv intervensjon.

Helsetjenesten - må prioritere underprivilegerte grupper og områder ("makro"), f.eks. barn i vanskeligstilte familier. Den må også fange opp pasienter med vanskelige kår ("mikro").

Skoler og barnehager - kan spille en avgjørende rolle for barn fra svake familier, med såkalte "umøblerte hjem".

Arbeidslivet - satser på økonomisk vekst, konkurranse og vinnere. Økonomien er kortsiktig og overlater problemene til samfunnet og til familien. Vi trenger et arbeidsliv for mennesker, ikke bare for profitt.

Politikerne - sitter med ansvaret for ulikhetene. I gamle dager var de fleste fattige og kunne vinne valgene. I dag har flertallet det bra og stemmer for skattelette, ikke for sosialt ansvar og solidaritet.

Konklusjonen er at vi har et felles ansvar for samfunnet og for fremtiden. Slagordet fikk vi for 150 år siden av Dostojevski: "Vi er alle ansvarlige for alle og for alt". Det er aldri for sent å begynne.

The article is based on the author's introduction to the section on "Health policy" in the Nordic conference on "Making a difference" at Gardermoen, May 14-16, 2001.

As a very young doctor, almost 50 years ago, I worked on a thesis on blood coagulation, and I needed blood from patients with haemophilia. At that time, these patients spent weeks and months in bed with very painful joint bleedings. They got no education, and their lives were endless miseries. I hoped that research could improve the treatment (which it did), but I also felt the need for social action. We started a patients' association to fight for their rights to services and education.
However, quite soon the mutual support between these socially isolated families became equally important. The association succeeded on both the external and the internal front (1), and today the haemophiliacs get education and jobs like everyone else.

A little later I went to Seattle in the United States as a research fellow in haematology. There are many people of Norwegian descent in Seattle, and many of them have been fishermen. I met some of them as pa- 
tients in the University Hospital, and they often had a sad and hard life. Disease had forced them to sell boat and house and had made them destitute. No wonder, I came home to Norway as a convinced social democrat, and inequities in the society have been a lifetime interest and commitment.

These stories illustrate that everybody wishes to be as healthy as possible and has a right to a fair deal from society. But nobody seems to accept the responsibility for this. Therefore, social inequities in health seem to be an everlasting problem, see Box 1.

In the following I shall briefly discuss five perspectives which are relevant to the problem: research, health services, schools and kindergartens, working life and politics.

\section{RESEARCH}

I start with research, because research must give us the basis for thinking about inequities in health and for doing something about them. I think there are four phases in this research, see Box 2:

Phase 1 is now well documented and almost overdone, although we always need to study present trends.

Phase 2 is also well covered.

Phase 3 is essential, because we need to understand the mechanisms in detail: How do low social position and resources increase the vulnerability for all diseases? The answers are obviously both complex and complicated (2). Especially, I think we need to know how and why social position and vulnerability continue for generations. It seems to me that many people are born into a tragic fate of failure, misery and poor health.

Phase 4 is the important studies on interventions, in order to learn what works and what does not. This, of course, is essential for good political initiatives.

Research is essential for progress in this field, and Norway has not done so well. I think it is important to build a strong international network for this research, to increase and systematize knowledge and to build political pressure for more and better research.

\section{HeALTH SERVICE}

The second perspective is the health service. There are two forms of social discrimination in the service:

One is macro, that is, too low priority to services which are of special importance to the underprivileged in the society. One example is service and support for children from families with problems. Often I have heard public health nurses say: "This child will surely have severe difficulties, but there is nothing I can do about it," and one added: "I can give you a list of the children in this community who are going to fail in life."

The other kind of discrimination is micro, that is, poor services to underprivileged patients. We see also the opposite, excessive services to overprivileged patients.
Box 1. Social inequities in health.

- are still with us

- are large and probably increasing

- are not limited to the poor, but cut through the entire population as a social gradient

- involve all diseases and causes of death

- probably also involve the health service

- hit individuals, but also areas and families

- often start in the fetus and increase throughout life

- require prevention (interventions), cannot be fixed by individual therapy

Box 2. Social inequities in health: phases in research.

1. Documentation of social inequities in health and mortality:

- magnitude and trends

2. Studies on causes:

- education, occupation, income

- life style

- working conditions

3. Studies on mechanisms:

- diseases and causes of death

- social gradient

- life course

- families and generations

4. Interventions and evaluation

Of course, we need research to document such differences and good interventions to eliminate them. The goal should be a positive discrimination, that is, a policy which favours such patients. Two very important areas are preventive measures for children and rehabilitation.

\section{SCHOOLS AND KINDERGARTENS}

The third perspective is the schools and the kindergartens. I was married to a primary school teacher for over 50 years. For about 20 years we used to argue about which service was most important - the schools or the health service. Then, I realized that she was right: the schools are the most important institutions in society, because they work with children, that is, with our future.

Experienced teachers and research tell us that childhood is decisive. The self image, the spirit and all the essential personality characteristics are determined early in life. Therefore, the public health nurses and the primary school teachers often prove to be right when they forecast the future of a child, especially for an underprivileged child. Thus, it often is now or never in kindergarten and primary schools. A teacher or a devoted grown-up can make the difference. We speak about "dandelion children", that is, children who succeed against heavy negative odds. The explanation often is that they, somehow, find a person who believes in them and encourages them. 
Often, the school system is negative for such children, because all the emphasis is on grades and competition. If I could chose one, and only one, intervention to reduce social inequities, it should be a program in schools and kindergartens to encourage children who risk failure, a program like the American Head Start. The effects of early interventions are well documented (3).

\section{WORKING LIFE}

The fourth perspective is working life, and Box 3 presents a shocking vision for the future. The present culture, or rather unculture, of rapid economic growth, ruthless competition, extreme economic gains and contempt for the losers is destructive and rewards inequity.

Box 3. A shocking vision for the future working life.

20\%: Leaders: power, responsibility, stress, money

40\%: Permanently employed: pressure, efficiency, reorganisations

20\%: Temporary and part-time jobs: insecurity, poverty

20\%: Outside working life: unemployed, disabled, sick

We need a radical change in the working life and in the work environment with emphasis on flexibility and mutual support, a working life for people. I think society needs to confront the present economic thinking which still is based on the philosophy of greed. In an essay entitled "Economic possibilities for our grandchildren" in 1930 John Maynard Keynes wrote: "For at least another hundred years we must pretend to ourselves and to everyone that fair is foul and foul is fair; for foul is useful and fair is not. Avarice and usury and precaution must be our gods for a little longer still. For only they can lead us out of the tunnel of economic necessity into daylight" (4). We belong to the generation of his grandchildren, and we have seen incredible economic growth, but social differences increase. The sad conclusion is that enough never is enough. Keynes was an expert of economy, but obviously not an expert of men. Some years ago it was said about a very successful economist: "He knows everything, but that is all he knows."

\section{Politics}

The fifth and last perspective is politics. Of course, the politicians carry the ultimate responsibility for all of my five perspectives, and the sad conclusion is that these issues carry little political weight. The reason is obvious: social inequities affect the minority, not the majority, and politics are about majority issues.

For a long period in our history, the left side - the social democrats - were responsible for the poor. But in that period the poor were the majority. Now they are a minority group, and an old Swedish social democrat, long-time mayor of a large city, shook his head and said to me: "You know, our party has sold its soul."

I have tried to argue with money. If I try to calculate society's costs for a loser, a person who fails in school, fails in society, fails in life and takes to alcohol, narcotics and crime, the total social costs may easily amount to 25 million NOK. Surely, it must be cheaper to try to prevent this. Therefore, I spent several months writing a proposal to the council in my municipality (5). The council discarded it and said that prevention was a personal, not a public responsibility. That was my background for the words I used in the title of this presentation: The responsibility of nobody.

\section{Conclusions}

This conference is about social inequities in health, and I believe the 10-90 rule (6) applies here too, as in the rest of public health. Thus, the health service is responsible for only $10 \%$ of the social inequities in health. All the institutions of the society carry the responsibility for the rest. In my view, we should concentrate our efforts on children and young people, and the schools are a major arena.

Dostojevskij has given us the masterword in book six of The Karamasov Brothers: "Each one of us is responsible to all men for everything, only people don't realise that. If they did - life would be a paradise at once!"

\section{REFERENCES}

1. Hjort PF. The haemophiliac in the society. Thromb Res 1992; 76: 339-44.

2. Evans RG, Barer ML, Marmor TR (eds). Why are some people healthy and others not? The determinants of health of populations. New York: de Gruyter, 1994.

3. Karoly LA, Greenwood PW, Everingham SS, Houbé J, Kilburn MR, Rydell CP, et al. Investing in our children. What we know and don't know about the costs and benefits of early childhood interventions. Santa Monica, CA: Rand, 1998.

4. Keynes JM. Essays in persuasion. London: McMillan, 1933.

5. Hjort PF, Damsgaard K. Enda bedre Bærum. Utredning om forebyggende og helsefremmende arbeid i Bærum. Bærum kommune, 1996.

6. Wildavsky A. Doing better and feeling worse: the political pathology of health policy. Proc Am Acad Arts Sci 1977; 106: 105-23. 